\title{
The Impact of the Religiosity on the Advertising Persuasion: Context of the Political Marketing - Frame of Reflection and Try of Modelling-
}

\author{
Askri Jendoubi Soumaya, Chakroun Ines, Mbarek Salma Ines \\ and Zouaoui Rejeb Nesrine
}

Institut Supérieur de Gestion de Tunis, Tunisie

Received date: 11 August 2013; Accepted date: 6 May 2014; Published date: 22 April 2015

Correspondence should be addressed to: Chakroun Ines; ines_chakroun@hotmail.fr

Academic Editor: Frederic Dosquet

Correspondence should be addressed to: Askri Jendoubi Soumaya; suemaya@yahoo.fr

Copyright (C) 2015. Askri Jendoubi Soumaya, Chakroun Ines, Mbarek Salma Ines and Zouaoui Rejeb Nesrine. Distributed under Creative Commons CC-BY 4.0

\begin{abstract}
From the current political situation in the Arab world, resulted a smooth confrontation between modernity and radicalism. It's a real identity crisis. Religion was even the core campaign's means to gain sympathy and to attract the maximum of voters. The match between those two areas (the religious marketing and the political marketing) is not so much obvious due to their heterogeneous logics. The Marketing researchers are shouted out by this phenomenon from which raises many managerial questions. The target of our research is to study the impact of the religiosity on the advertising persuasion: context of the political marketing taking into consideration the socio-demographic characteristics of the electoral platform. A review of literature and a frame of reflection will permit to encircle the various relations between these variables to end to our model.
\end{abstract}

Keywords: religiosity, political marketing, advertising persuasion.

\section{Introduction}

A new horizon and perspective are offered and open to Tunisia since 2011, January the14th, this horizon has brought a whole set of changes in the Tunisian's life.

The change concerns especially the relationship between the Tunisian, politics and the politicians.

Tunisian have become more and more attracted and concerned by politics considered as enigmatic for them for several years and after the blown wind of change, Tunisian have become fascinated, intrigued at the highest level.

The worn in the last elections (October 2011) testifies of their awareness and of the politics incidence on their everyday life.

Being aware of this radical change to Tunisians, politicians have worked on their images, polished up their speeches and some of them have received training 
courses on the gestural communication. Politics married then clothing, the elements of the marketing mix to push itself forward with voters.

It was the first time in Tunisia, that political campaigns are led by the various parties. Various axes of communications and stimuli are used during these campaigns. The effect of some of these stimuli on the advertising persuasion in the political frame will be treated throughout this article.

We are going to concentrate essentially on the effect of religiosity on the advertising persuasion exerted by the voters. Indeed, many young people, today, suffer from an identify problem and they are in search of their own identity, membership...

The politicians were interested in this phenomenon and we saw that speeches completely different from those who laud the religion to those who defend secularism. Having seen the importance of the subject and its contributions, we are going to analyze the impact of religiosity on the advertising persuasion by the voters.

\section{Political Marketing}

The application of marketing's technique in policy was created in the 30's by Roosevelt, Thirty-the second President of the United States, during the development of his economic recovery plan called the "New Deal". After World War II, the use of marketing's techniques mix in policy spreads in the United States, mainly during the presidential elections (Eisenhower in 1952), but also on any ballot. These practices spread across the Atlantic and become current in any political event (Boy Dupoirier and Meynaud 1985).

In France, during the presidential campaign of 1965 (candidate Lecanuet), Bongrand introduced political marketing. Gradually this technique was spread across the political game. Thus, boosting the dissemination and the recognition of political marketing as a discipline.

Political marketing is considered as "the use of marketing mix elements in policy to designate a set of theories, methods, techniques and social practices inspired by the commercial marketing, which are intended to persuade citizens to give their support to a man, a group or a political project "(Alouby 1994).

According to Achache (2008), Political marketing is also conceptualized. It's the only purely instrumental model deprived of ideology. It should be noted that while we tend to associate the political marketing to political communication, the latter is more extensive since it covers all the phenomena of communication between the politician and his "target" (Alouby 1994).

It mainly concerns "the exchange of information between governors and governed by formal or informal means" (Cotteret and Emery). These exchanges are organized to achieve specific goals.

Alouby (1994) identify two kinds of political communication. The first type is an informative communication, whose purpose is to transmit untargeted information. The second type is a persuasive communication aimed to influence the attitude, the behavior and people's opinions in order to boost their support for a politician, a party or community.

To determine the profile of the potential citizens who will be joining the electoral base, politicians use different techniques. Two main approaches were used by the "professional" political marketing appeared (Boy Dupoirier and Meynaud 1985):

The socio-political approach supported by politicians and the cultural approach supported by professional advertisers.

The socio-political approach has its roots in political science. It is based on the classic sociological model. Its purpose tends to determine the strongest interests in the electorate that consists of analyzing the socio-political data and recognizing the structural determinants of individual behavior. This approach advocates the credibility of the electoral message and the dominance of the logic of persuasion.

The Cultural Approach preached the investigation of cultural politics. It is an extension of the motivation studies of the fifties. It is based on the definition of "socio- 
style" as "practical life model of expression and thought."

When trying to make the analogy between commercial marketing and political marketing, many differences appear. Commercial marketing works the image of a product to cause a purchasing act. Based on this observation, a product isn't a politician. Indeed, by voting for a politician or a party, we don't derive any tangible benefit. Lindon (1986) outline the objectives and programs ... in order to influence the behavior of citizens.

We must also distinguish the difference between the act of voting and purchasing act. Indeed, we note in political marketing willingness to "packager" men and political ideals as consumer products. This hypothetical encroachment of the political field by the commercial field will alter the political act of voting and modify a simple act of purchasing a product.

Based on these findings, to better understand and mainly to act the behavior of voters, we will try to analyze the impact of religiosity on advertising persuasion in the context of political marketing.

\section{Religiosity}

Religion has a strong influence on the behavior of the consumer as well as on his decisions. (Sfar,2005). This influence apparent in many levels: social, economic, ethics (Vitell and Paolillo, 2003) and cultural. It can also touch the consumer behavior which depends on the degree of religiosity and religious affiliation.

As a matter of fact, many authors have emphasized the status of religion as a cultural specificity determining behaviors, attitudes and perceptions of individuals in their relationships with others (Hofstede, 1991, Schwartz and Huismans, 1995; Saroglou et al, 2005 and 2008 Scheitle, 2005).

Religiosity or religious commitment is "the degree to which an individual is dedicated to religion and professes his teachings of how attitudes and behaviors reflect this commitment" (Johnson et al, 2001).
For Worthington et al (2003), religiosity is the "degree to which a person adheres to his/her values, beliefs and religious practices and uses them in his/her life" Thus, people who are highly committed evaluate the world through religious patterns and integrate in many dimensions of life (Worthington et al, 2003).

Delener (1990) presents religiosity as one of the most important forces and cultural influences upon the consumer's behavior. Thus, the degree of religiosity has an impact on the determination of consumer's behavior. Through literature, we identified different scales of religiosity (which will be presented in Appendix 1).

Synthetic review proposed by Khraim (2010) shows that most of the empirical studies examining measures of religiosity were inspired by American culture, confined to the Christian community. It appears that these scales are related to the culture and therefore unsuitable for measuring religiosity in an Islamic context.

Regarding this reflection, we used the scale developed by Worthington et al (2003). Measures RCI-10 measuring the motivational and behavioral systems to religious values commitment, has been validated in different samples (Mokhlis, 2009).

Thus, the cognitive dimension of religiosity which is the motivational commitment focuses on the faith of the individual or the personal religious experience. For the behavioral dimension, it concerns the level of individual participation in religious activities (Mokhlis, 2009).

The scale proposed by Worthington et al (2003) presents a real asset. Indeed, the scale cleverly avoids sectarian language using more appropriate terms for extension to all religions as "my faith" and "my religious group."

The scale consists of ten items measured in 7 point Likert-type statements from "Strongly disagree" (1) to "strongly agree" (7) (Appendix 2). 
Thus, we have until now few studies on the factors that explain the impact of the degree of religiosity on advertising persuasion. Hence the following hypothesis: the higher the degree of religiosity, the greater the religious content of an announcement will be privileged.

\section{Advertising Effectiveness}

The studies treating the topic of advertising effectiveness abound in literature. The advertising effectiveness can be defined as "the extent to which advertising generates some effect of desired communication" (Buschken, 2007). In other words, advertising effectiveness is the process by which we measure causal relationship between creative advertising (input) and purchasing behavior (output). Several theories of advertising effectiveness are recognized, considered in three main approaches: (1) the economic approach, (2) the cognitive approach and (3) the emotional approach.

The economic approach: Under this approach, advertising is considered as an input of production that must necessarily lead to satisfactory economic returns for its investors. Under this approach, advertising effectiveness is assessed in terms of:

- Performance of the market (Porter, 1976): The efficiency is measured through the return on advertising investment, that is to say, the effect of advertising investment on market power.

- Sales Volumes (Kinnucan and Forker, 1986): The advertising effectiveness is estimated by using a ratio of sales on advertising.

- Consumption patterns (Atkins, Hocking and Block, 1984): The effectiveness of advertising is assessed according to a regression model estimating the effect of advertising exposure on the consumption behavior.

- Nevertheless, this approach has been criticized. Indeed, "charging the economic and financial company's results to an advertising campaign even important could be truly risky" (Kammoun , 2008).
Other factors may significantly affect the advertising effectiveness.

- The cognitive approach has dominated the marketing research for a long time. Cognitive models of advertising persuasion are synthesized in the work of Eagly and Chaiken (1984). They are divided into (1) hierarchy effects models of and (2) information processing models.

- Hierarchy effects models: The sequential view of persuasive advertising was proposed by St Elmo Lewis in 1898, according to which the necessary steps to advertising persuasion are: Attention Interest - Desire. This model will be completed later to lead to the famous AIDA model (Attention - Interest - Desire Action). The term "hierarchy effects" appeared for the first time in the article Palda in 1966. Lavidge and Steiner (1961) proposed the whole hierarchy effects model formed by six stages: Product Notoriety - Product Knowledge - Product Evaluation - Preference for the Product Conviction - Purchase. Here are discerned three main functions of advertising communication: the cognitive (Notoriety and Knowledge), the affective (evaluation and preference) and finally the conative function (conviction and purchase).

- Theories based on the information processing: The paradigm of information processing was born in Yale School and would be formalized later by McGuire (1968-1972) in the model of advertising persuasion, which consists of six steps: Presentation - Attention- Retention Acceptance - Understanding - Action.

The most famous models based on the theory of information processing are the ELM (Elaboration Likelihood Model) and HSM (Heuristic - Systematic Model), corresponding respectively to Cacciopo and Petty (1981) and Chaiken (1980).

- The ELM model suggests two routes of persuasion: a central route where the receiver performs a thorough assessment of relevant information showed by the advertising message, and a peripheral road, where the attitude is dependent on the peripheral elements contained in the message (music, message length, etc. .) . 
- The HSM model assumes two modes of processing the advertisement. The first is systematic, according to which a considerable cognitive effort is made by the exposed person to understand and develop the arguments of the message. The second mode is rather heuristic outcome of observation and \ or experience of the advertising message receiver.

Both models involve the moderating role of motivation and of processing capacity. However, cognitive approaches are undermined by a current implementing non-cognitive phenomenon in explaining the effect of persuasive advertising. These include, for example, the theory of mere exposure (Zajonc, 1968), classical and instrumental conditioning, the three hierarchies of Ray et al. (1973). Similarly, the approach by the attitude toward the advertisement found its origin in the work of Shimp (1981) and Mitchell and Olson (1981) has shown the inadequacy of the cognitive reaction in explaining the change attitudes. Thus, Mitchell and Olson (1981) involve another mediator of the formation of attitudes they designate by Attitude toward the announce (Aad). All these criticisms of the cognitive approach lead to reconsider its principles and use rather emotional approaches.

The emotional approach is considered as the radical critique of advertising persuasion cognitive models, conducted by Holbrook and Batra (1987). Indeed, the insufficiency of the cognitive models was performed by several models where the role of emotions in the formation and change of attitudes is highlighted. We can mention, as such, the model of low involvement of Krugman (1965) and the model of normative beliefs of Fishbein and Ajzen (1975). A current research installed by Zajonc (1980) and Zajonc and Markus (1982) separates the cognitive process from the emotional processes. On the other hand, the introduction of another type of emotional responses adds to the attitude toward the ad, namely the attitude toward the brand (Ab) (eg Holbrook, 1978; Lutz, McKenzie and Belch, 1983, Mitchell and Olson, 1981; Shimp, 198, etc. ) .

In short, plenty of models treating the advertising persuasion show a clear evolution. Initially dominated by the cognitive paradigm, understanding the persuasive effect of advertising involves the emotions from the eighties. Although the coexistence of the two approaches has remained difficult for a long time, MacInnis and Jaworski (1991) proposed an integrative model that encompassed these two views. Their main aim was to connect emotions and cognitive responses to treatment levels and attitude formation process.

It is through a proposed content in the announcement that the persuasion process can take place. The hypothesis encompassing this relationship is as follows: " the religious content or not of an announcement has an impact on the advertising persuasion and hence on the poll intentions".

Explanatory Model of the Impact of Religious Content on Advertising Effectiveness of a Political Campaign while Integrating the Degree of Religiosity.

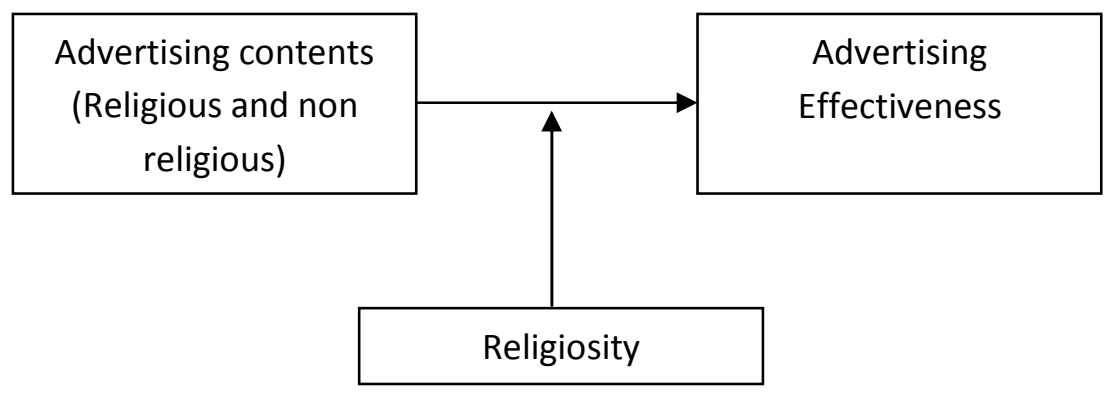

Fig.1. The Impact of Religious Content on Advertising Effectiveness of a Political Campaign While Integrating the Degree of Religiosity 
The litterature review led us to propose the following model of the relationship between the use of a religious content in a political campaign and the degree of religiosity on advertising effectiveness (Figure 1).

This model summarizes the different assumptions made in the previous paragraphs. Thus, once the voter is exposed to a political party's advertisement, his reaction will depend on its content but also on the degree of religiosity.

Moreover, the more the voter has a high degree of religiosity, the more it will be sensitive to the religious content of political campaigns. Further, the more he will be sensitive to the content of the advertising, higher will be the probability to choose this party at the crucial moment of voting. Indeed, the advertising content's appreciation will depend on the voters' degree of religiosity.

\section{Conclusion}

The objective of this study is to propose a preliminary explanatory model to better explain the relationship between the use of a religious content in a political campaign and religiosity on advertising effectiveness. This objective is fulfilled by trying to integrate different advertising contents (religious and non-religious) and different degrees of religiosity to better explain this effectiveness.

Our goal, by studying the religiosity effects on advertising effectiveness, is to enrich the theory of modeling customer behavior, especially the voters. To our knowledge, no marketing research has studied the impact of religiosity on advertising effectiveness of a political campaign.

Although this work is unfinished, we hope to contribute to marketing research in general, and in particular political and religious Marketing. Indeed, we propose to test our global model, using the experimentation method that will allow us to test different advertisings that we create and the structural equation method to verify its plausibility.

However, several questions need to be asked and considered as future research area: the understanding degrees of the advertising messages, the need to integrate graphics and other symbolic elements (colors, shapes, characters ...), social affiliation and socio0demographic characteristics of prospective voters in the study of the impact of religiosity on advertising effectiveness.

Appendix

\section{1: Presentation of Religiosity Various Scales Measure}

\begin{tabular}{|l|l|}
\hline Auteurs & Echelles \\
\hline $\begin{array}{l}\text { Bardis (1961) } \\
\text { Kaufmann (1999) }\end{array}$ & Mesure de l'attitude envers les croyances et les pratiques religieuses \\
\hline Hoges (1972) & Mesure de la motivation religieuse intrinséque \\
\hline $\begin{array}{l}\text { Cohen (1978) } \\
\text { (1982) Ventis }\end{array}$ & Quête \\
\hline $\begin{array}{l}\text { Kirkpatrick et Hood, } \\
\text { (1990); Genia (1996) }\end{array}$ & Orientation religieuse (ROS) \\
\hline Sandage (1999) & Mesure des valeurs religieuses \\
\hline Worthington et al & l'utilisation de l'inventaire d'engagement religieux « Religious Commitment \\
\hline
\end{tabular}


2003 Inventory » qui permet de mesurer le degré de religiosité à travers l'engagement cognitif et comportemental interpersonnel et intra personnel à un système de valeur religieux

\section{2: The Scale Proposed by Worthington Et Al (2003)}

\begin{tabular}{|c|c|}
\hline & 1234567 \\
\hline $\begin{array}{l}\text { Mes croyances religieuses s'étendent derrière toute mon approche de vie et toutes } \\
\text { mes relations. }\end{array}$ & 0000000 \\
\hline Je consacre du temps pour améliorer la compréhension de ma religion. & 0000000 \\
\hline $\begin{array}{l}\text { Il est important pour moi de passer des périodes de temps dans la pensée religieuse } \\
\text { privée et de réflexion. }\end{array}$ & 0000000 \\
\hline Les croyances religieuses influencent toutes mes relations dans la vie. & 0000000 \\
\hline $\begin{array}{l}\text { La religion est spécialement importante pour moi parce qu'elle répond à plusieurs } \\
\text { questions qui concernent le sens de la vie. }\end{array}$ & 0000000 \\
\hline Je regarde souvent des programmes télévisés reliés à ma religion. & 0000000 \\
\hline $\begin{array}{l}\text { J'aime participer aux activités religieuses (prière collective, lire ou apprendre le } \\
\text { coran, visiter des pauvres). }\end{array}$ & 0000000 \\
\hline $\begin{array}{l}\text { J'aime partager mon temps avec d'autres personnes qui sont de mêmes confessions } \\
\text { religieuses que moi. }\end{array}$ & 0000000 \\
\hline $\begin{array}{l}\text { Je demeure bien informé (e) de toutes les activités réalisées par ma communauté de } \\
\text { confessions tout en participant à la prise de décision. }\end{array}$ & 0000000 \\
\hline Je contribue financièrement aux activités de ma communauté de confessions & 0000000 \\
\hline
\end{tabular}

\section{References}

1.Achache, G. (2008). 'Le Marketing Politique,' in Mercier, A., p. 53-68.

2.Alouby. S. (1994). 'Marketing et Communication Politique,' L'Harmattan.

3.Atkin, C., Hocking, J. \& Block, M. (1984). "Teenage Drinking: Does Advertising Make a Difference?," Journal of Communication, Vol $34, \mathrm{n}^{\circ} 2$, pp 157-167.

4.Boy, D., Dupoirier, E., \& Meynaud, H.Y. (1985). "Le Marketing Politique : de la Conviction à la Séduction," Pouvoirs n³3 Les sondages, p.121-130.
5.Buschken, J. (2007). "Determinants of Brand Advertising Efficiency: Evidence from the German Car Market," Journal of Advertising, Vol. 36, $\mathrm{n}^{\circ} 3$.

6.Chaiken, S. (1980). "Heurestic Versus Systematic Information Processing and the Use of Source Versus Message Cues in Persuasion," Journal of Personality and Social Psychology, Vol. 39, n5, pp. 752-766.

7.Cotteret, J.M. \& Emeri, C. (1994). 'Les Systèmes Electoraux, Que Sais-Je,' Presses Universitaires France.

8.Delener, D. (1990). "The Effects of Religious Factors on Perceived Risk in Durable Goods Purchase Decisions," Journal of Consumer Marketing, Vol. 7, n³, pp.27 - 
38.

9.Eagly, A. \& Chaiken, S. (1984). "Cognitive Theories of Persuasion, Advances in Experimental Social Psychology," Vol. 17, pp 267-359.

10.Fishbein, M. \& Ajzen, I., (1973). 'Attitudinal and Normative Variables as Predictors of Specific Behaviours,' Journal of Personality and Social Psychology, Vol. 27, $\mathrm{n}^{\circ} 1, \quad$ pp. 41-27.

11.Fishbein, M. \& Ajzen, I., (1975). 'Beliefs, Attitude, Intention and Behavior: An Introduction to Theory and Research,' New York : Addison Wesley.

12.Hofsted, G. (1991). "'Cultures and Organization: Software of the Mind,' Berkshire UK, MC Graw-Hill.

13.Holbrook, M.B. \& Lehmann, D.R., (1980). "Form versus Content in Predicting Starch Scores," Journal of Advertising Research, Vol. 20 (August). pp. 53-62.

14. Hirschman, E.C. \& Holbrook, M.B. (1982). "Hedonic Consumption: Emerging Concepts, Methods and Propositions," Journal of Marketing, Vol.46, pp.92-101.

15.Holbrook, M.B. \& Batra, R., (1987). "Assessing the Role of Emotions as Mediators of Consumer Responses to Advertising," Journal of Consumer Research, Vol. 14, pp.404-420.

16.Jonhson, B.N., Jang, S. J., Larson, D.B. \& De Li, S. (2001). "Does Adolescent Religious Commitment Matter? A Reexamination of the Effects of Religiosity on Delinquency," Journal of Research in Crime and Delinquency, Vol. 38, $n^{\circ} 1$, pp 22-44.

17.Kammoun, M. (2008). "Efficacité de la Publicité," La Revue des Sciences de Gestion, Vol. 43, n²29, pp. 111-119.

18.Khraim, H. (2010). "Measuring Religiosity in Consumer Research from an Islamic Perspective," Journal of Economic and Administrative Sciences, Vol. 26, Issue 1, pp.52 - 78 .
19.Kinnucun H. \& Forker, O. D. (1986). "Seasonality in the Consumer Response to Milk Advertising with Implications for Milk Promotion Policy," American Journal of Agricultural Economics, Vol. 68, n³, pp 562571.

20.Krugman, H.E. (1965). "The Impact of Television Advertising: Learning without Involvement," Public Opinion Quaterly, Vol. 29, n³, pp.349-356.

21.Lavidge, R.J. \& Steiner, G.A., (1961). "A Model for Predictive Measurements of Advertising Effectiveness," The Journal of Marketing, Vol. 25, n6, pp. 59-62.

22.Lindon, D. (1986). 'Le Marketing Politique,' Dalloz.

23.Lutz, R.J., Mackenzie S.B. \& Belch, G., (1983). "Attitude toward the $\mathrm{Ad}$ as a Mediator of Advertising Effectiveness : Determinant and Consequences," in Advances in Consumer Research, vol.10, R.P. Bagozzi, ed.Ann Arbor, MI Association for Consumer Research, pp.532-539.

24.Macinnis, D.J., Moorman, C. \& Jaworski, B.J., (1991). "Enhancing and Measuring Consumers' Motivation, Opportunity and Ability to Process Brand Information from Ads," Journal of Marketing, Vol. 55, pp.32-53. 25.Maarek (2001). 'Communication et Marketing de l'homme Politique,' Paris.

26.Mitchell, A.A. (1981). "The Dimensions of Advertising Involvement," Advances in Consumer Research, vol.8, pp.25-30.

27.Mitchell, A.A. \& Olson, J.C., (1981). "Are Product Attribute Beliefs the Only Mediator of Advertising Effects on Brand Attitude?," Journal of Marketing Research, vol.27, pp. 209-219.

28.Mokhlis, S. (2009). "Relevancy and Measurement of Religiosity in Consumer Behavior Research," International Business Research, Vol. 2, n³, pp. 75-84.

29.Palda, K.S., (1966). "The Hypothesis of a Hierarchy of Effects: A Partial Evaluation," Journal of Marketing Research, Vol. 3, ${ }^{\circ} 1$, pp. 13-24. 
30.Petty, R.E., Cacioppo, J.T. \& Goldman, R., (1981). "Personal Involvement as a Determinant of Argument-based Persuasion," Journal of Personality and Social Psychology, Vol. 41, n5, pp. 847-855.

31.Porter, M.E. (1976). "Interbrand Choice, Media Mix and Market Performance," The American Economic Review, Vol. 66, n²2.

32.Saroglou, V. \& Muñoz-GARCÍA, A. (2008). "Individual Differences in Religion and Spirituality: An Issue of Personality Traits and/or Values," Journal for the Scientific Study of Religion, Vol. 47, n¹, pp 83-101.

33.Saroglou, V., Pichon, I., Trompette, L., Verschueren, M. \& Dernelle, R. (2005). "Prosocial Behavior and Religion: New Evidence Based on Projective Measures and Peer Ratings," Journal for the Scientific Study of Religion, Vol. 44, $\mathrm{n}^{\circ} 3$, pp323-348.

34.Scheitle, C.P. (2005). "In God We Trust: Religion and Optimism Toward Biotechnology," Social Science Quarterly, Vol. 86, ${ }^{\circ} 4$, pp 846-856.

35.Schwartz, S.H. \& Huismans, S. (1995). "Value Priorities and Religiosity in Four Western Religions," Social Psychology Quterly.

36.Sfar, A., (2005). L'influence des Facteurs Psychoculturels sur le Comportement Responsable du Consommateur: Proposition d'un Cadre Conceptuel
Préliminaire, Colloque Association Tunisienne du marketing.

37.Shimp, T.A. (1981). "Attitude toward the Ad as a Mediator of Consumer Brand Choice," Journal of Advertising, Vol.10, pp. 915.

38.Vitell, S. J., Paolillo, J.G.P. \& Thomas, J.L. (2003). "The Perceived Role of Ethics and Social Resonsibility: A Study of Marketing Professional," Business Ethics Quarterly. Vol. $13, n^{\circ} 1$, pp. 63-86.

39.Worthington, E L, Wade, N. G., Hight, T. L., Ripley, J. S., Berr,y J. W., Schmitt, M. M. \& Bursley, K. H. (2003). "The Religious Commitment Inventory-10: Development, Refinement, and Validation of a Brief Scale for Research and Counseling,", Journal of Counseling Psychology, Vol. 50, n. 1, pp. 8496.

40.Zajong, R.B., (1968). 'Cognitive Theories in Social Psychology,' chap 5 de Lindzey Aranson, Handbook of social psychology, Cambridge, Addison- Wesley.

41.Zajonc, R.B. (1980). "Feeling and Thinking: Preferences Need no Inferences," American Psychologist, Vol. 35, pp.151-175.

42.Zajonc, R.B. \& Markus, H., (1982). "Affective and Cognitive Factors in Preferences," Journal of Consumer Research, Vol.12, pp.363-364. 